\title{
Yüksek Fruktoz İçerikli Beslenmenin Overlerde Perilipin Ekspresyonu ve Polikistik Over Gelişimi ile İlişsisi
}

\author{
Relationship Between Maintaining Diet Containing High Fructose and Development of Polycystic Ovary Via \\ Perilipin Expression
}

\author{
İlknur KESKİN ${ }^{1-2}$, Nejda BEDRİ ${ }^{1}$
}

1. Istanbul Medipol Üniversitesi Tıp Fakültesi Histoloji ve Embriyoloji Anabilim Dalı, İstanbul

2. İstanbul Medipol Üniversitesi Rejeneratif Ve Restoratif Tıp Araştırmaları Merkezi (REMER), İstanbul

\section{$\ddot{O Z Z T T}$}

Amaç: PCOS ve yüksek fruktoz içerikli diyet birlikteliğini gösteren çalışmalar kısıtlı sayıdadır. Çalışmamızda ratlarda yüksek fruktoz içerikli beslenmenin overlerde perilipin ekspresyonu üzerine etkisi ve Polikistik Over gelişimi ile ilgisini değerlendirildi.

Gereç ve Yöntem: Çalışmamızda hiçbir uygulama yapılmayan Kontrol (K) grubu, Yüksek Fruktoz (HF) grubu ve DHEA (dehidroepiandrosteron) enjekte edilen Hormon (H) grubu over yapıları karşılaştırıldı. Gruplar arasındaki morfolojik farklılıkları gösterebilmek için hematoksilen-eozin boyamast yapıld , PLIN2 ve PLIN3 antikorlart için western blot yöntemi uygulandi. Progesteron ve LH seviyeleri ELISA tekniği ile ölçüldü.

Bulgular: $H F$ ve Hormon gruplarinda antral ve preantral folikül sayısının artmış olduğu gözlendi. PLIN2 ve PLIN3 ekspresyonlarinin Hormon ve HF gruplarında yüksek olduğu görüldü. Progesteron ve LH seviyelerinde anlamll bir farklılık saptanmadı.

Sonuç: Yüksek fruktozlu diyet ile beslenme PCOS oluşumuna neden olabilir ve bu mekanizmada PLIN2 ve PLIN3 proteinlerinin aşırı ekspresyonu etkili olabilir.

Anahtar Kelimeler: fare; fruktoz; ovaryum; PCOS; perilipin

\section{ABSTRACT}

Objective: Studies showing diet consisting of PCOS combined with high fructose are in a limited level. In this study, it is aimed to investigate PLIN2 and PLIN3 expressions by showing diet consisting of combination of high fructose and PCOS.

Material and Method: A total of 26 Balb/C type female mice have been used and 3 groups are created: Control (no treatment), HF (tap water containing $20 \%$ fructose is given by oral gavege) and Hormone (The injection of DHEA is injected s.c.). In order to show the morphological differences between the groups haematoxylin and eosin staining method has been used. For PLIN2 and PLIN3 antibodies western blot method has been used. ELISA technic has been used to compare progesterone and LH levels between the groups.

Results: It is seen that antral and preantral follicle numbers of HF and Hormone groups have increased. It is also seen that PLIN2 and PLIN3 expressions are high in HF and Hormone groups.

Conclusion: As a result diet with high fructose could contribute to PCOS development and in this mechanism PLIN2 and PLIN3 proteins could also be effective.

Keywords: mice; fructose; ovary; PCOS; perilipin

\footnotetext{
İletişim Bilgileri

Sorumlu Yazar: Yrd. Doç. Dr. İlknur KESKIN

Yazışma Adresi: İstanbul Medipol Üniversitesi, Tıp Fakültesi,

Histoloji ve Embriyoloji AD.Beykoz, İstanbul, Türkiye

E-posta: ilknurkeskin@medipol.edu.tr

Tel: +90 (216) 5815354

Makalenin Geliş Tarihi: 22.10.2016

Makalenin Kabul Tarihi: 09.11.2016

DOI: http://dx.doi.org/10.16948/zktipb.257211
} 


\section{GİRIȘ}

Polikistik over sendromu (PCOS) kronik anovulasyon, hiperandrojenizm ve ultrasonografide polikistik ovaryumlar ile karakterizedir [1]. PCOS'ta menstrüel düzensizlikler, hirşutizm, akne, alopesi, anovulatuar infertilite ve tekrarlayan gebelik kayıpları gözlenmektedir. Aynı zamanda insülin direnci, obezite, lipid anormallikleri, glukoz tolerans testinde bozulma ve artmış Tip 2 diabetes mellitus riski ile bağlantıdır. Üreme çă̆ındaki kadınlarda görülme sıklı$\breve{g} 1$ ise \%5-13,9 arasındadır [1-3]. Beslenmedeki başlica fruktoz kaynaklarından biri olan yüksek fruktozlu misir şurubu (High Fructose Corn Syrup-HFCS), \%55-90 oranında fruktoz içermektedir. HFCS, 1970'li yıllarda, Amerika Birleşik Devletleri (ABD)'de tüm kalorili tatlandırıcılarin \%1'ini temsil ederken, bu oran 2000'li y1llarda \%42'ye yükselmiştir. HFCS, gazlı ve meyve aromalı içecekler, çikolata, şeker ve reçel gibi birçok ișlenmiș üründe yaygın bir șekilde kullanılmaktadır [4]. ABD' de doğurganlık çağındaki kadınlar günlük enerji ihtiyaçlarının $\% 23$ 'ünden fazlasını tatlandırılmış içeceklerden karşılamaktadırlar [5].

Günlük diyet ile alınan fruktoz miktarının artması ile birlikte vücutta glikojen sentezi, lipogenez ve trigliserid (TG) sentezi de artmaktadır $[6,7]$. Aşırı fruktoz alımı ile birlikte insulin direnci oluşmaktadır [8]. PCOS'taki insulin direnci sonucu oluşan hiperinsulinemi obezitedekinden bağımsızdır. PCOS ve obezite kombinasyonu glukoz insulin dengesini bozarak ovaryan stereogenezi teșvik etmektedir [9]. Bunun sonucu olarak PCOS'ta insulin direnci kaynaklı hiperinsulinemiye aynı zamanda hiperandrojenizm de eşlik etmektedir. Bu olay PCOS'ta küçük antral foliküllerin granüloza hücre luteinizasyonlarına neden olmakta, hücre çoğalması ve folikül büyümesi durmaktadır. Hiperandrojenizm, erken folliküler atreziye ve bunun sonucunda oligo-/ anovulasyona neden olmaktadır [10-13]. Bazal koșullarda serum androstenedion seviyesi antral folikül sayısını belirlemektedir. PCOS hastalarındaki yüksek serum androjen seviyesi artan 2-5 $\mathrm{mm}$ çapındaki foliküller ile pozitif korelasyon göstermektedir [14, 15]. Hücre içi sitoplazmik yapılar olan Lipid Dropletler (LD), hücre içerisindeki lipidleri metabolik enerji, membran bileşeni, protein modifikasyonu ve sinyal molekülü gibi birçok hücre içi olayda kullanmak üzere, TG olarak depolamaktadırlar [16, 17]. LD, özel proteinler içeren fosfolipid yapıda bir tabaka ile çevrilidirler $[18,19]$. Bu özel proteinlerden biri olan perilipin (PLIN), LD dinamiğinde önemli bir role sahiptir [20]. LD'in yüzeyini örten PLIN, sitozolik TG'in hormon sensitif lipaz (HSL) tarafindan hidrolize edilmesini engeller. PLIN ve HSL, siklik adenozin monofosfat (cAMP) bağımlı protein kinaz A (PKA) ile fosforile edilerek aktive olmaktadır. Bu basamak, HSL regülasyonunda kilit öneme sahiptir ve lipolizin hız kısıtlayıcı basamağını oluşturur [21]. PLIN bu işlevi ile yağ damlacıkları ve hücresel çevre arasındaki regülasyonu sağlamaktadır. Daha önceki çalışmalar ile PLIN'in lipid yıkımını engelleyip, lipid birikimini teşvik ettiği gösterilmiştir. Farklı dokularda ekspresyon farklılıkları gösteren 5 farklı alt tipi bulunmaktadır [22]. Yapılan çalışmalarda \%30 fruktoz ile beslenen farelerde PLIN2 ekspresyonunun up-regüle olduğu saptanmıştır [23]. PCOS olan kadınların derialtı yağ dokusunda PLIN1, PLIN3 ve PLIN5' in kontrol grubuna göre $\% 90$ daha az eksprese olduğu; PLIN2 ve PLIN4'ün ise kontrol grubuna göre 3 kat daha fazla eksprese olduğu saptanmıştır [24]. Özellikle PLIN2 ve PLIN3'ün, oositlerde eksprese olduğu yapılan çalışmalar ile ortaya konmuştur (21). Hayvan modelleri ile yapilan çalışmalar, PLIN2 ve PLIN3'ün oosit matürasyonunda ve erken embriyo gelişiminde önemli rol oynadığını göstermiştir [25-27]. Bu bilgiler 1şığında, yüksek fruktoz içerikli beslenmenin, PLIN2 ve PLIN3 expresyonlarında meydana gelecek değişiklikler üzerinden PCOS gelişimine neden olabileceğini düşünmekteyiz.

\section{GEREÇ VE YÖNTEM}

İstanbul Medipol Üniversitesi Bilimsel Araştırma Projeleri ve Rejeneratif ve Restoratif Tıp Araştırmaları Merkezi (REMER) tarafindan desteklenen çalışma, İstanbul Medipol Üniversitesi Hayvan Deneyleri Yerel Etik Kurulu (İMÜ-HADYEK, EK No: 38828770-604.01.01E.2562) tarafindan belirlenmiş olan deney hayvanları bakım, kullanım ve ötenazi protokolüne uygun olarak gerçekleştirildi. Çalışmamızda Medipol Üniversitesi Tıp Fakültesi Deney Hayvanları Araştırma Merkezinden elde edilen 26 adet $\mathrm{Balb} / \mathrm{C}$ dişi fareler kullanıldı. Denekler deney süresince 12 saat aydınlık-12 saat karanlık periyoduna uyularak, sicaklığ $122 \pm 2^{\circ} \mathrm{C}$ olarak ayarlanmış bir ortamda bakıldı. Hayvanlar 12 hafta boyunca standart fare yemi ile beslendi ve içme suyu olarak çeşme suyu verildi. Deneklere uygulama her sabah 09.00-12.00 arasi yapild 1 ve ağırlıkları haftalık olarak tartıldı.

Deney Grupları: HF (High Fructose) grubu $(n=10) ; 28$ günlük farelere standart diyet uygulandı ve 12 hafta boyunca oral gavaj ile ağırlı̆̆ 1 dikkate alınarak $\% 20$ fruktoz içeren çeşme suyu verildi.

H(Hormon) grubu $(\mathbf{n}=\mathbf{8})$; 92 günlük farelere 20 gün boyunca DHEA (dehidroepiandrosteron, 6 $\mathrm{mg} / 100 \mathrm{~g} / \mathrm{gün})$ susam yağında çözdürülerek (0.01 $\mathrm{ml} \mathrm{95 \%} \mathrm{etanol} \mathrm{içerisinde} \mathrm{çözülerek} \mathrm{ve} 0.09 \mathrm{ml} \mathrm{su-}$ sam yağı ile karıştırılarak) subkutan enjekte edildi. 
K (Kontrol) grubu (n=8); 28 günlük fareler 12 hafta boyunca standart yem ile beslendi ve hiçbir uygulama yapılmadı.

Ovaryum Ôrneklerinin Alınması ve Hazırlanması: $\mathrm{HF}$ ve $\mathrm{K}$ gruplarındaki deneklere 12 haftanın, $\mathrm{H}$ grubundaki deneklere 20 günün sonunda intraperitoneal olarak ksilazin $(10 \mathrm{mg} /$ $\mathrm{kg})$ ve ketamin $(100 \mathrm{mg} / \mathrm{kg})$ anestezisi uygulandı. Doku diseksiyonu yapılmadan önce tüm hayvanlardan LH (Lüteinleștirici Hormon) ve Progesteron Hormon düzeylerinin belirlenebilmesi amacı ile kan örnekleri alındı ve santrifüj edilerek serumları alınıp $-80^{\circ} \mathrm{C}$ 'de muhafaza edildi. Deneklerin ağrılı uyaranlara cevap vermedikleri anlaşıldıktan sonra, abdominal bölgeleri açıldı ve her iki overleri de çıkarıldı. Bir tanesi 1ş1k mikroskobik preparasyon için \%10'luk nötral tamponlu formalin (Sigma\#SLBK3646V) içerisine, diğeri ise Western blot analizi için kuru buz üzerine alındı. Fikse olan dokular 24 saat musluk suyunda y1kandı ve rutin histolojik takip protokolü uygulandı. Parafin bloklamanın ardından mikrotom (Thermo SCIENTIFIC, Microtom HM 340E) ile $5 \mu \mathrm{m}$ kalınlığında kesilen dokular adheziv lamlara alınd.

Hematoksilen-Eozin Boyama ile Histolojik İnceleme: Hematoksilen (\#2311; Bio-Optica) - Eozin (\#5114; Bio-Optica) boyamas1 rutin protokollere uygun şekilde yapıldı [28]. Kesitler Işık Mikroskobu (Nikon, ECLIPSE Ni) ile görüntülenip fotoğrafları çekildi ve gruplar morfolojik olarak incelenip karşılaştırıldı.

Western Blot Analizi: Tartılan overler uygun miktarda T-PER (Thermo Scientific\# 78510) örnek tampon ve protez inhibitörü (PMSF, Roche\#10837091001) eklenerek homojenizatörde (Next Advance, Bullet Blender) homojenize edildi. Santrifüj (10.000 RPM) sonrası örneklerden süpernatantları alındı ve Qbit ile total protein miktarı tespit edildi. Hazırlanan stok proteinlerden alınan uygun miktardaki örnekler, yükleme solüsyonu (2x Laemmli Sample, BioRad\# 161-0737) ile 1:1 oranda karıștırıldıktan sonra $95^{\circ} \mathrm{C}$ 'de 5 dakika kaynatıldı. Çalışılacak olan proteinin kilo dalton ağırlığ 1 dikkate alınarak, uygun yüzdelerde jellere, $30 \mu \mathrm{g} / \mathrm{ml}$ oranında protein içeren numuneler yüklendi. Numuneler elektroforezde 80V 30mA'de 10 dakika ve ardından 120V 30mA'de jelin sonuna kadar yürütüldü. Jeldeki proteinleri membrana aktarmak için immunoblotting yapıld1. Proteinlerin transferinden sonra, \%0.1 Tween-20 ilaveli Tris Buffer Solüsyonu (TBS-T, $\mathrm{pH}=7.4$ ) ile y1kand 1 ve membran 1 saat oda isında TBS-T ile hazırlanan \%5'lik yağsız süt tozu ile bloklandı. Daha sonra membran PLIN2 antikoru ile 1 saat karıștırıcı üzerinde oda 1sısında inkübe edildi. Ardından TBS-T ile 3 kez 10 dakika yıkanarak, sekonder antikorla oda sıcaklığında karıştırıcı üzerinde 1 saat inkübe edildi. İnkübasyon sonrasında TBS-T ile $3 \mathrm{kez}$
10 dakika yıkanıp chemiluminisans ile 5 dakika karanlıkta inkübe edildi. Membrandaki protein bantların görüntülenmesi Chemi DOC MP İmaging Sistem (Bio-Rad) ile yapıldı. Membranlar PLIN3 ve $\beta$ - actin antikorları için de $+4^{\circ} \mathrm{C}^{\prime}$ de 1 gece karıştırıcı üzerinde inkübe edildi. Geri kalan aşamalar PLIN2'deki gibi aynen uygulandi.

ELISA (Enzyme Linked Immunosorbent Assay): ELISA için $-80^{\circ} \mathrm{C}$ 'den çıkarılan serumların buz üstünde erimeleri beklendi. Progesteron (\#E-EL-M0944, Elabscience) ve LH (\#E-EL-M0057, Elabscience) ELISA kitleri üreticinin tavsiyesi doğrultusunda oda 1sısına getirildi. Konsantre y1kama solüsyonu, konsantre biyotinlenmiş antikor ve konsantre HRP konjugatı ile sulandırıldı. Her kuyucuğa hangi örneğin ve standartın konacağı belirlendi ve kayıt edildi. ELISA testi için standart, örnek ve QC solüsyonlarının her birinden $100 \mu$ l alınarak uygun kuyucuklara koyuldu, 30 saniye karıștırıldı ve üzeri parafilm ile kapatılarak 90 dakika $37^{\circ} \mathrm{C}$ 'de inkübe edildi. Kuyucukların içeriği boşaltıldı ve her kuyucuk üzerine biyotinlenmiş enzim konjuge progesteron / LH solüsyonundan $100 \mu \mathrm{l}$ eklendi, 30 saniye karıştırıld 1 ve $37^{\circ} \mathrm{C}^{\prime}$ de 1 saat inkübasyona bırakıldı. Süre bitiminde kuyucukların içeriği boşaltıldı ve tüm kuyucuklar $3 \mathrm{kez}$

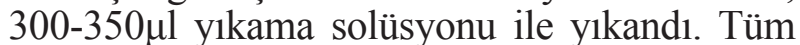
kuyucuklara $100 \mu 1$ HRP konjugatı eklendi ve 30 dakika $37^{\circ} \mathrm{C}$ 'de inkübe edildi. Kuyucukların içeriği boşaltıldı ve tüm kuyucuklar 5 kez, 300-350 $\mu$ l yıkama solüsyonu ile yıkandı. Tüm kuyucuklara $90 \mu \mathrm{TMB}$ substrat solüsyonundan eklendi ve 15 dakika $37^{\circ} \mathrm{C}$ 'de inkübe edildi. Ardından $50 \mu 1$ durdurma solüsyonu eklenerek yavaşça karıștırıldı. Kuyucuklar SpectraMax i3 Spektrofotometrede $450 \mathrm{~nm}$ dalga boyunda okutuldu.

İstatistiksel Değerlendirme: İstatistiksel analizler için SPSS 18.0 (SPSS 18 for Windows; SPSS Inc. Chicago, IL, USA) istatistik paket programı kullanıldı. Çalışma grupları tekyönlü varyans analizi (One- way ANOVA) ile değerlendirildi ve gruplar arası farklılıklar Tukey's HSD testi ile karşılaştırıldı. $\mathrm{p}<0.05$ değeri istatistiksel olarak anlamlı kabul edildi.

\section{BULGULAR}

Deneklerin ilk ve son ağırlıklarına bakıldığında 12 hafta süreyle HF uygulanan farelerin kontrol ve hormon grubuna göre daha fazla kilo aldığ1 ancak bunun istatistiksel olarak anlamlı olmadığı gözlendi ( $\mathrm{p}>0,05)$.

Hematoksilen-Eozin Boyama ile Grupların Morfolojik Olarak Değerlendirilmesi: Fare östrus siklusunun çok kısa olması sebebi ile kesit görüntülerinde, farklı gelişim aşamalarına ait foliküller bir arada gözlendi. Primordiyal, primer, preantral ve antral foliküller ve korpus luteumlar tespit edildi. Histolojik olarak, 
HF ve Hormon grubu farelerde, normal gruba göre over dokusunda antral ve preantral folikül sayısının ve teka kalınlığının artmış olduğu, bunun yanında HF ve Hormon gruplarında foliküler kist benzeri yapılar görüldü (Figür 1).

Western Blot Analizi Bulguları: HF ve Hormon gruplar1 Kontrol grubu ile kiyasland1ğında PLIN2 ve PLIN3'ün artmış olduğu görüldü (Figür 2). Western Blot ölçümler iki kez tekrarlandığından istatistiksel bir değerlendirme yapılamasa da HF ve Hormon gruplarına ait değerler Kontrol grubuna göre daha yüksek ölçüldü.

ELISA Bulguları: ELISA yöntemi ile Progesteron ve LH için standart konsantrasyon eğrileri oluşturuldu (Figür 3). Progesteron hormon seviyesinin kontrol grubuna göre diğer iki grupta daha düşük olduğu, LH seviyesinde ise kontrol grubuna göre diğer iki grupta da hafif artmış olduğu belirlendi ancak istatistiksel olarak anlamlı bir farklılık saptanmadı (Tablo 2).

Tablo 1: Gruplarda gözlenen ortalama kilo artış miktarları.

\begin{tabular}{|c|c|c|c|}
\hline GRUPLAR & HF & H & K \\
\hline Ortalama Kilo Artışı & $6,6 \mathrm{gr}$ & $4,3 \mathrm{gr}$ & $0,5 \mathrm{gr}$ \\
\hline
\end{tabular}

Tablo 2: ELISA sonuçları ( $p>0,05)$.

\begin{tabular}{|c|c|c|c|}
\hline GRUPLAR & HF & H & K \\
\hline Ort. Progesteron (ng/ml) & 1.9 & 1.9 & 2.7 \\
\hline Ort. LH $(\mathrm{ng} / \mathrm{ml})$ & 14.6 & 14.8 & 13.0 \\
\hline
\end{tabular}

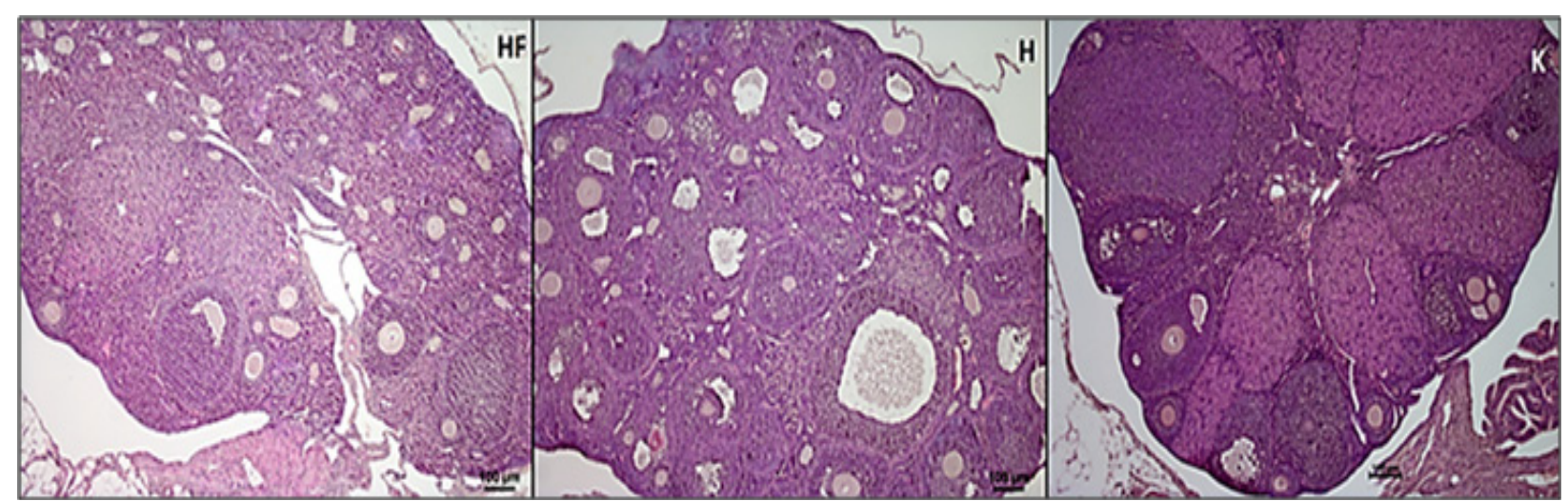

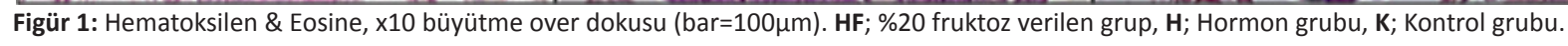

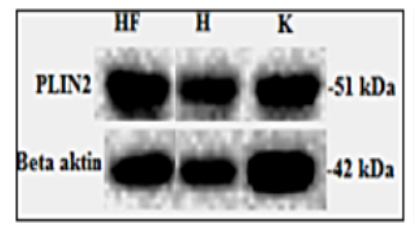

PLIN2

Figür 2: PLIN2 ve PLIN3 western bantları.

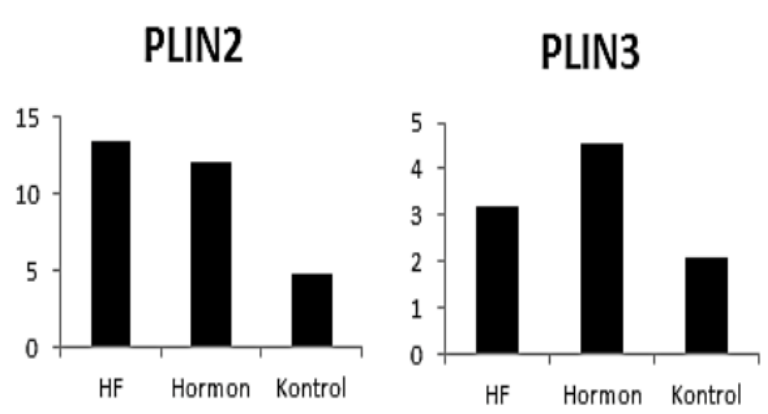

\section{TARTIŞMA}

Son yıllarda lipid damlacıkları ve onları saran perilipinler hakkında literatür bilgisi gelişme göstermiştir. Perilipin adipositlerde lipid damlacıklarını kaplayan bir proteindir [18]. Lipid damlacıkları merkezde nötral lipid içerir, etrafinı ise tek tabaka fosfolipid sarar. Perilipinler lipid damlacıkların yüzey proteinleridir ve total hücre proteininin \%0.25-0.5' ini oluştururlar. Perilipinler kabaca adipositlerin koruyucu ve düzenleyici proteinleridir [22]. Bir nevi lipidi lipaz enzimlerinin lipolizinden koruyan fiziksel bir bariyer görevi görürler. Adipositlerdeki lipoliz perilipinin fosforlanması ile regüle edilir. Perilipin geni knockout edilmiş ratlarda hormon sensitif lipazların sürekli aktif olduğu, bu hayvanların diet ile indüklenebilen ve genetik temelli obeziteye dirençli oldukları gözlenmiştir [29]. İnsanlarda da Perilipin geni varyasyonları obezite ve artmış lipid seviyeleri ile ilișkilendirilmiştir. Kadınlarda en sık görülen endokrin bozuklardan biri olan PCOS un etiyolojisinde de obezitenin çok önemli rolü olması perilipin ile PCOS arasında olası bir ilişkiyi akla getirmektedir. Bundan önce çeşitli çalışmalarda kadınlarda perilipin geninin varyasyonları ile obezite, insülin resistansı ve glukoz intoleransı ile ilişkili metabolik anomaliler arasında ilişkiler gösterilmiştir [30].

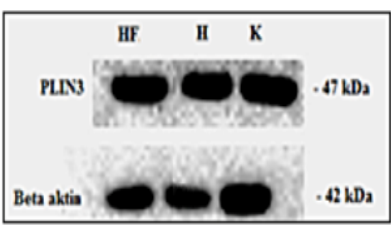

HF Hormon Kontrol

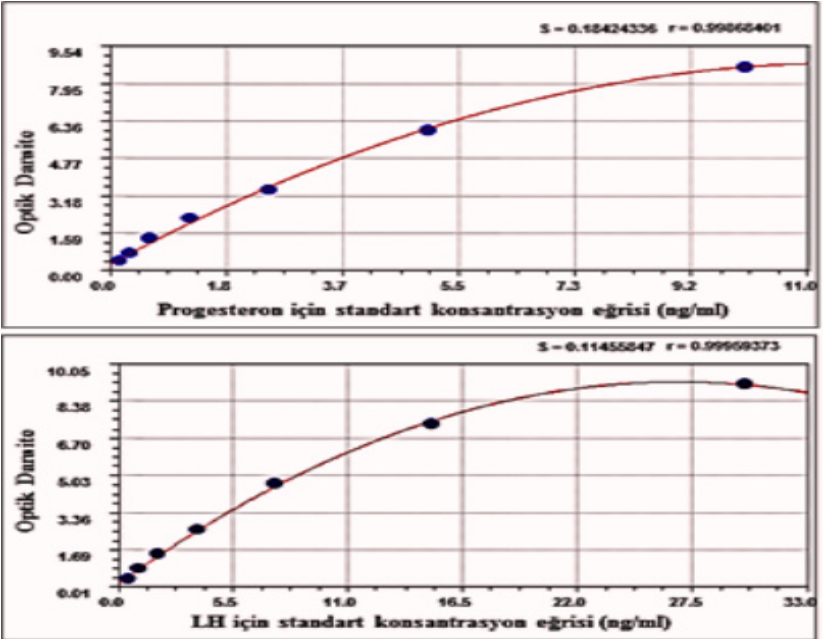

Figür 3: ELISA standart konsantrasyon eğrileri. 109 - 
Bașka bir çalıșmada PCOS'lu kadınlarda lipaz aktivitesinin ve lipolizin olumsuz etkilendiği gösterilmiştir [31].

Sonuç olarak; HF ve Hormon gruplarına ait over kesitlerinde PCOS ile uyumlu artmış folikül gelişimi ve atretik folikül yapılarının izlenmesi, PLIN2 ve PLIN3 ekspresyonlarının bu iki grupta da kontrol grubuna göre yüksek olmas1, progesteron ve LH seviyelerinin PCOS'lu kadınlarda gözlenen hormonal değişiklikler ile benzerlik göstermesi yüksek fruktoz içeren diyetle beslenmenin PLIN2 ve PLIN3 ekspresyonunu artırarak PCOS gelișiminde etkili olabileceği hipotezimizi güçlendirmiştir.

\section{KA YNA KLAR}

1. Ehrmann DA. Polycystic ovary syndrome. $N$ Engl J Med 2005;352(12):1223-36.

2. Melo AS, Vieira CS, Barbieri MA, Rosa-E-Silva AC, Silva AA, Cardoso VC et al. High prevalence of polycystic ovary syndrome in women born small for gestational age. Hum Reprod 2010;25(8):2124-31.

3. Norman RJ, Dewailly D, Legro RS, Hickey TE. Polycystic ovary syndrome. Lancet 2007;370(9588):685-97.

4. Vos MB, Kimmons JE, Gillespie C, Welsh J, Blanck HM. Dietary fructose consumption among US children and adults: the Third National Health and Nutrition Examination Survey. Medscape J Med 2008;10(7):160

5. Storey ML, Forshee RA, Anderson PA. Beverage consumption in the US population. J Am Diet Assoc 2006:106(12):19922000.

6. Feinman RD, Fine EJ. Fructose in perspective. Nutr Metab (Lond) 2013;10(1):45.

7. Parks EJ, Skokan LE, Timlin MT, Dingfelder CS. Dietary sugars stimulate fatty acid synthesis in adults. J Nutr 2008;138(6):1039-46.

8. Lecoultre V, Egli L, Carrel G, Theytaz F, Kreis R, Schneiter $P$ et al. Effects of fructose and glucose overfeeding on hepatic insulin sensitivity and intrahepatic lipids in healthy humans. Obesity (Silver Spring) 2013;21(4):782-5.

9. Dunaif A. Insulin resistance and the polycystic ovary syndrome: mechanism and implications for pathogenesis. Endocr Rev 1997; 18(6):774-800

10. Franks $S$, Gilling-Smith C, Watson H, Willis D. Insulin action in the normal and polycystic ovary. Endocrinol Metab Clin North Am 1999;28(2):361-78.

11. Franks S, Mason H, Willis D. Follicular dynamics in the polycystic ovary syndrome. Mol Cell Endocrinol 2000;163(12):49-52.

12. Morin-Papunen LC, Vauhkonen I, Koivunen RM, Ruokonen A, Tapanainen JS. Insulin sensitivity, insulin secretion, and metabolic and hormonal parameters in healthy women and women with polycystic ovarian syndrome. Hum Reprod 2000;15(6): 1266-74.

13. Pasquali R, Gambineri A. Metabolic effects of obesity on reproduction. Reprod Biomed Online 2006;12(5):542-51.
14. Dumesic DA, Damario MA, Session DR, Famuyide A, Lesnick TG, Thornhill ARet al. Ovarian morphology and serum hormone markers as predictors of ovarian follicle recruitment by gonadotropins for in vitro fertilization. J Clin Endocrinol Metab 2001:86(6):2538-43.

15. Jonard S, Robert Y, Cortet-Rudelli C, Pigny P, Decanter C, Dewailly D. Ultrasound examination of polycystic ovaries: is it worth counting the follicles? Hum Reprod 2003;18(3):598-603.

16. Wang H, Bell M, Sreenivasan U, Hu H, Liu J, Dalen K et al. Unique regulation of adipose triglyceride lipase (ATGL) by perilipin 5, a lipid droplet-associated protein. J Biol Chem 2011;286(18):15707-15.

17. Murphy DJ. The biogenesis and functions of lipid bodies in animals, plants and microorganisms. Prog Lipid Res 2001;40(5):325-438.

18. Thiele C, Spandl J. Cell biology of lipid droplets. Curr Opin Cell Biol 2008;20(4):378-85.

19. Walther TC, Farese RV Jr. The life of lipid droplets. Biochim Biophys Acta 2009;1791(6):459-66.

20. Holm C. Molecular mechanisms regulating hormone-sensitive lipase and lipolysis. Biochem Soc Trans 2003;31(6):1120-4.

21. Khor VK, Shen WJ, Kraemer FB. Lipid droplet metabolism. Curr Opin Clin Nutr Metab Care 2013;16(6):632-7.

22. Bickel PE, Tansey JT, Welte MA. PAT proteins, an ancient family of lipid droplet proteins that regulate cellular lipid stores. Biochim Biophys Acta 2009;1791(6):419-40.

23. Liu X, Xue R, Ji L, Zhang X, Wu J, Gu J et al. Activation of farnesoid $X$ receptor $(F X R)$ protects against fructose-induced liver steatosis via inflammatory inhibition and ADRP reduction. Biochem Biophys Res Commun 2014;450(1):117-23.

24. Covington JD, Bajpeyi S, Moro C, Tchoukalova YD, Ebenezer PJ, Burk DH et all. Potential effects of aerobic exercise on the expression of perilipin 3 in the adipose tissue of women with polycystic ovary syndrome: a pilot study. Eur J Endocrinol 2015;172(1):47-58.

25. Sastre D, da Costa NN, de Sá AL, Conceição SD, Chiaratti MR, Adona PR et al. Expression of PLIN2 and PLIN3 during oocyte maturation and early embryo development in cattle. Theriogenology 2014;81(2):326-31.

26. Yang X, Dunning KR, Wu LL, Hickey TE, Norman RJ, Russell $D L$ et al. Identification of Perilipin-2 as a lipid droplet protein regulated in oocytes during maturation. Reprod Fertil Dev 2010;22(8):1262-71.

27. Zhang RN, Fu XW, Jia BY, Liu C, Cheng KR, Zhu SE. Expression of Perilipin 2 (PLIN2) in Porcine Oocytes During Maturation. Reprod Domest Anim 2014;49(5):875-80.

28. Cardiff RD, Miller CH, Munn RJ. Manual hematoxylin and eosin staining of mouse tissue sections. Cold Spring Harb Protoc 2014; 6:655-8.

29. Shen WJ, Patel S, Miyoshi H, Greenberg AS, Kraemer FB. Functional interaction of hormone-sensitive lipase and perilipin in lipolysis. J Lipid Res 2009;50(11):2306-13.

30. Yan W, Chen S, Huang J, Shen Y, Oiang B, Gu D. Polymorphisms in PLIN and hypertension combined with obesity and lipid profiles in Han Chinese. Obes Res 2004;12:1733-7.

31. Manneras-Holm L, Leonhardt H, Kullberg J, Jennische E, Oden A, Holm G, et all. Adipose tissue has aberrant morphology and function in PCOS: enlarged adipocytes and low serum adiponectin, but not circulating sex steroids, are strongly associated with insulin resistance. J Clin Endocrinol Metab 2011;96(2):304-11. 